called Political Research Online or PROceedings.

Through PROceedings, APSA and Harvard University Library have teamed up to increase the accessibility and reach of papers presented at the Annual Meeting. This year, Bill Ball, in cooperation with the 1997 Annual Meeting Program Committee, initiated a pilot project that has made 135 of the papers from the 1997 meeting available online.

In addition to the consultants, focus groups are being assembled at regional political science meetings this year to assess the value of this service and the ease of use. All APSA members are urged to visit the site at http://PRO.harvard.edu, search for topics of interest, download one or more papers, and then fill in the survey in order to let the creators of the project know their assessments of it. Comments may also be directed to PROceedings@apsanet.org.

The abstracts of all posted papers are searchable, and the papers themselves can be easily downloaded using Adobe Acrobat. This is the same freeware used by government agencies to make large files publicly accessible, and allows accurate transmission not only of text but also charts, graphs, tables, and strings of symbolic logic. Instructions for downloading Adobe Acrobat are available on the PROceedings site.

\section{APSA Hosts \\ International Delegations}

During the Fall of 1997 the Association hosted visiting delegations of schlolars from both Poland and Vietnam. In November six Polish teachers of civics met with members of the APSA staff as part of the APSA's participation in the International Civic Education Exchange program. Members of the delegation included: Lidia Korecka, Ewa Bobinska, Ewa Koclcjda, Jaroslaw Pietrzak, Elizbieta Krolikowska, and Katarzyna Koazewska.

Sheilah Mann, APSA Director of Educational Affairs, coordinated the visit with the American Federation of Teachers and hosted the teachers during their half-day visit. Among the activities were a briefing by Dr.
Mann on the status of civic education in the United States, an introduction by APSA Staff Associate Jun Yin to the Association's ongoing international programs, and a demonstration of the Association's web site. Executive Director Catherine Rudder joined the group for lunch and informal discussion. A variety of APSA publications, including directories, course syllabi collection, State of the Discipline II, APSA Ethics Guide, Political Science: An Ideal Liberal Arts Major, Earning a Ph.D. in Political Science, and multiple issues of PS: Political Science \& Politics, and American Political Science Review, were distributed to the teachers attending the meeting. The APSA also provided a one-year complimentary membership to each.

Later in November a delegation of six Vietnamese political scientists from the Ho Chi Minh National Political Academy visited the National Office. This delegation was led by Julie Bunck of the University of Louisville and co-sponsored by the American Council of Learned Societies and Princeton University. The delegation visited the United States seeking knowledge, experience, and guidance from American political scientists in an effort to establish political science as a rigorous and independent discipline in Vietnam. The delegation included Le Huu Nghia, Ho Van Thong, Nguyen Dang Thanh, Tran Danh Tao, Ho Ngoc Minh, and Vu Viet Dung.

Catherine Rudder greeted the delegation and introduced the Association and its major functions and activities. APSA Staff Associate Jun Yin briefed the delegation on the Association's ongoing international programs and Jeffrey Biggs, Director of APSA's Congressional Fellowship Program, introduced the Congressional Fellowship Program and the Association's efforts to extend the international component of this program. The visit concluded with a demonstration of the Association's web site. A variety of APSA publications and promotional materials were presented as gifts to the delegation.

\section{IPSA World Congress Set for Quebec in 2000}

Following a successful event in Seoul, South Korea, the $18^{\text {th }}$ International Political Science Association World Congress has been scheduled to take place August 1-6, 2000 in Quebec City. William Lafferty of the University of Oslo and Prosus (Program for Research and Documentation for a Sustainable Society) has been selected to serve as Program Chair. A program committee and theme for the Congress have not yet been named. Cochairs of the local organizing committee are Guy La Chapelle, Concordia University, and John E. Trent, University of Ottawa.

All queries regarding the upcoming Congress should be directed to either the IPSA Secretariat at International Political Science Association, Department of Politics, University College Dublin, Belfield, Dublin 4, Ireland; Phone: 353-1-706-8182; Fax: 353-1-706-1171; E-mail: ipsa@ucd.ie; or Dr. Guy Lachapelle at Département de science politique, Concordia University, 7141 rue Sherbrooke Ouest, Montréal, Quebec H4R 1R6, Canada; Phone: (514) 987-3000 ext. 4582; Fax: (514) 9874878; Email: sqsp@er.uqam.ca.

IPSA also maintains a web site at http://www.ucd.ie/ ipsa/.

\section{Minority Identification Project Joined by Seven New Core Schools}

Seven graduate programs have recently joined APSA's Minority Identification Project as core departments. The programs are Miami University $(\mathrm{OH})$, University of Missouri at Columbia, University of New Mexico, University of New Orleans, Washington State University, University of California, Santa Barbara, and University of Southern California. These new additions bring the total number of core participants to 41 .

To participate, a Ph.D. program is asked to: (1) Submit names of undergraduate minority students to the program. Faculty in undergraduate programs meet with minority stu- 
dents and discuss professional careers in political science and submit to APSA the names of promising minority candidates whom they have pre-screened. (2) Attend the Minority Identification Project Breakfast for core graduate schools at the APSA Annual Conference. The faculty member acting as primary contact for the Project is asked to attend the APSA-hosted breakfast. (3) Contribute financially to the Project by purchasing mailing labels for an annual fee, currently, of $\$ 100$. (4) Actively recruit students identified by the Project. For these students they should:

a. invite/solicit applications from these students.

b. be willing to waive application fees.

c. offer full funding/fellowships for the students whom they accept.

Any Ph.D. program interested in participating and willing to meet the above requirements may request to become a core school. Please contact Jun Yin at jyin@apsanet.org.

\section{APSA Announces 1998-99 Minority Graduate Student Fellows}

APSA has named four Minority Graduate Fellows for 1998-99.

These students were chosen out of a highly impressive pool of diverse candidates representing the best schools throughout the country.

Three funded Fellows include Luz Inéz Gómez (Latina) of the University of California, Berkeley; Kimberly Clark (African American) of Rutgers University; and Temita Davis (African American) of North Carolina A \& T University.

One non-funded Fellow, Brandy Faulkner of Averett College was named as well. These Fellows, both funded and nonfunded, typically receive full support from universities as a result of their status as APSA Fellows. Many departments eagerly await the selection of Fellows in early December.

APSA Minority Fellowships were established to increase the number of minorities with doctoral degrees in political science. Fellowships are

\section{S I T E S E E I N G Political Science on the Web}

The World Wide Web hosts a wide range of information sources in political science, from governement sites to compilations offered by individual scholars. Among this growing selection of sites are those developed by the Organized Sections of the APSA. With concentration on a particular subfield, these sites provide scholars with access to the latest research in the field - through database archives, conference papers, and detailed bibliographies - to teaching materials that include syllabi, classroom excerices, and comments shared by colleagues in the profession. Below you will find a listing of those Sections maintaining web sites at this time.

\section{Law and Courts}

www. artsci.wustl.edu/ polisci/lawcourt.htm

\section{Public Policy}

www.fsu.edu/ spap/orgs/apsa.html

\section{Public Administration}

www.apsanet.org/ pubadmin

\section{Conflict Processes}

wizard.ucr.edu/cps/cps.html

Presidency Research
sunsite.unc.edu/lia/prgnet

\section{Political Methodology}

wizard.ucr.edu/polmeth/polmeth.html

\section{Religion and Politics}

www.gac.edu/Academics/poli-sci/relpol/r\&p.html

\section{Urban Politics}

thecity.sfsu.edu/ urbanpol

Science, Technology and Environmental Politics www2.ncsu.edu/ncsu/chass/mds/steps.html

\section{Women and Politics}

www.apsanet.org/ wpol

\section{Foundations of Political Theory}

www.apsanet.org/ theory

\section{Computers and Multimedia}

www.apsanet.org/ $\sim \mathrm{cms}$

\section{State Politics and Policy}

www.apsanet.org/ - state

\section{Politics and History}

www.sscnet.ucla.edu/polisci/apsa/index.html

\section{Domestic Sources of Foreign Policy}

www.apsanet.org/ $\sim \mathrm{dsfp}$

Race, Ethnicity and Politics

www.providence.edu/polisci/rep 